\title{
Errata for Biological and Pharmaceutical Bulletin
}

\begin{tabular}{|c|c|c|c|c|}
\hline Vol. & Page & Line & Error & Correction \\
\hline \multirow[t]{3}{*}{38} & 127 & \multirow{3}{*}{$\begin{array}{l}\text { left } 5 \\
\text { REFERENCES }\end{array}$} & \multirow[t]{3}{*}{ regenerative medicine. $\frac{1,2)}{2}$} & regenerative medicine. $\frac{15,16)}{2}$ \\
\hline & 133 & & & $\begin{array}{l}\text { 15) Takahashi K, Yamanaka S. Induction of pluripotent stem } \\
\text { cells from mouse embryonic and adult fibroblast cultures by } \\
\text { defined factors. Cell, 126, 663-676 (2006). }\end{array}$ \\
\hline & & & & $\begin{array}{l}\text { 16) Okita } \mathrm{K} \text {, Ichisaka T, Yamanaka } \mathrm{S} \text {. Generation of germline- } \\
\text { competent induced pluripotent stem cells. Nature, 448, } \\
313-317 \text { (2007). }\end{array}$ \\
\hline
\end{tabular}

